Z Badań nad Książką i Księgozbiorami Historycznymi 2019. T. specjalny: Dla Niepodległej The Studies into the History of the Book and Book Collections 2019. Special issue: For an Independent Poland

Ewa Andrysiak

Uniwersytet Łódzki

eandrysiak@interia.pl

ORCID 0000-0002-5949-6130

\title{
Biblioteki w systemie powiatowej oświaty pozaszkolnej w okresie międzywojennym. Na przykładzie powiatu kaliskiego i tureckiego
}

\author{
Abstract \\ Libraries in the non-formal county educational system, \\ in the interwar period. On the example of the Kalisz \\ and Turek district
}

The topic of the paper are the contests of a document, titled "Guidelines for arranging and conducting non-formal education" and activities based on it which were conducted in Kalisz and Turek district. The paper presents the works of education authorities which were led in the interwar period in a more or less spontaneous way and sets some rules of non-formal educational work, as one of the most important fragments of Polish education within this time period. Big emphasis was placed on the activities of libraries which were an essential element of supporting non-formal education. The author of the work describes the forms and methods of the library work for the non-formal education, showing the less known side of the library and educational activities, conducted by the newly-reborn Polish state.

Key words: educational libraries - mobile libraries - extracurricular education - Kalisz (district) - Turek (district).

Słowa kluczowe: biblioteki oświatowe - biblioteki ruchome - oświata pozaszkolna - Kalisz (powiat) - Turek (powiat).

„Z Badań nad Książką i Księgozbiorami Historycznymi” - Udział zagranicznych recenzentów w ocenie publikacji; Stworzenie anglojęzycznej wersji wydawniczej publikacji; Digitalizacja tomów archiwalnych rocznika w celu zapewnienia otwartego dostępu do nich przez Internet oraz wdrożenie i utrzymanie cyfrowej platformy redakcyjnej - zadanie finansowane w ramach umowy $\mathrm{nr}$ 653/P-DUN/2019 ze środków Ministra Nauki i Szkolnictwa Wyższego przeznaczonych na działalność upowszechniającą naukę. 
Stan oświaty pozaszkolnej i miejsce w niej bibliotek w okresie międzywojennym

Początki oświaty dorosłych w dzisiejszym rozumieniu tego terminu sięgają w Europie przełomu XVIII i XIX w., co związane było z nową epoką w zakresie gospodarki, a także życia społecznego zapoczątkowaną ideami oświecenia. W przypadku Polski upadek Rzeczypospolitej skierował działania entuzjastów nowej idei w stronę oświecenia warstwy mieszczańskiej oraz, przede wszystkim, chłopskiej, tworząc w ten sposób zaczątek formowania się współczesnego narodu polskiego. W okresie zaborów jednym z najważniejszych działań w tym zakresie pozostawała organizacja oświaty dorosłych nastawiona zarówno na uświadomienie narodowe niższych warstw społecznych, jak też (a może przede wszystkim) na walkę z analfabetyzmem ${ }^{1}$.

Ten właśnie nurt oświaty dorosłych stał się szczególnie istotny po odzyskaniu niepodległości w 1918 r., a to z racji wypełniania zadania wspierania budzenia poczucia narodowego już przez oficjalne instytucje państwa polskiego. Nadal jednak pozostawała kwestia niewysokiego stopnia alfabetyzacji społeczeństwa, zwłaszcza w odniesieniu do jego starszej części, niepodlegającej już obowiązkowi szkolnemu. Sytuacja ta wymagała zorganizowania systemu pracy oświatowej, a warto przypomnieć, że zjawisko analfabetyzmu na terenie międzywojennej Polski było szczególnie widoczne na obszarach dawnego zaboru rosyjskiego. W tym także czasie zaczęto mówić o oświacie pozaszkolnej, ponieważ system szkolny II Rzeczypospolitej obejmował, przynajmniej teoretycznie, wszystkich młodych ludzi w wieku szkolnym. Tak więc pojęcie oświaty dorosłych możemy w rzeczywistości Polski okresu międzywojennego utożsamić z pojęciem oświaty pozaszkolnej.

Zagadnienia oświaty pozaszkolnej w Polsce skupiały się więc w międzywojniu przede wszystkim na walce $\mathrm{z}$ analfabetyzmem (organizacja sieci kursów początkowych), dokształcaniu w zakresie szkoły powszechnej (kursy uzupełniające) oraz dokształcaniu zawodowym i pogłębianiu wykształcenia ogólnego obywateli ${ }^{2}$. Jak istotna to była kwestia w owym czasie świadczyć może wydanie przez Prezydenta Rzeczypospolitej 4 X 1933 r. Rozporzadzenia o organizacji obwodowych władz szkolnych, które nakładało na inspektora szkolnego obowiązek sprawowania opieki nad oświatą pozaszkolną (art. 3) $)^{3}$. Przepisy wykonawcze w tym zakresie powierzono Ministrowi

1 J. Nowak, Oświata dorostych - cele, zadania, funkcje, uczestnicy [hasło], [w:] Encyklopedia oświaty i kultury dorostych, pod red. K. Wojciechowskiego, przy współpracy C. Maziarza, J. Nowak, Wrocław 1986, s. 207-208.

2 Oświata pozaszkolna [hasło], [w:] Podręczna encyklopedia pedagogiczna. Wraz z dodatkiem i dwoma indeksami. T. 2: N-Ż, oprac. F. Kierski, Lwów-Warszawa 1925, s. 353.

3 Rozporządzenie Prezydenta Rzeczypospolitej z dnia 4 lipca 1933 r. o organizacji obwodo- 
Wyznań Religijnych i Oświecenia Publicznego, który w rozporządzeniu z 25 sierpnia tego roku określał odpowiedzialność inspektora szkolnego w zakresie oświaty pozaszkolnej ${ }^{4}$. W skład tychże działań wchodziła opieka nad bibliotekami oświatowymi, dostarczającymi systemowi oświaty pozaszkolnej wartościowych lektur.

W 1922 r. Sejm rozważał, opracowany przez rząd, projekt ustawy „o obowiązku zakładania kursów początkowych i bibliotek powszechnych”. Projekt ten, przewidujący nałożenie obowiązku organizowania początkowych kursów dla dorosłych i bibliotek powszechnych na powiatowe związki komunalne i miasta wydzielone z tych związków, wycofany został przez Ministerstwo Wyznań Religijnych i Oświecenia Publicznego (MWRiOP) ${ }^{5}$.

Pozostająca w sferze projektów kwestia ,jednolitej organizacji oświaty pozaszkolnej, stosunek do niej państwa, samorządów i organizacji społecznych o charakterze kulturalno-oświatowym" wpłynęła na to, że szereg organizacji prowadziło działania na własną rękę . Pracą kulturalno-oświatową w Warszawie zajmowały się: Towarzystwo Szkoły Ludowej (TSL, zał. w 1891 r.), Polska Macierz Szkolna (PMS, 1906), Kursy dla Dorosłych m.st. Warszawy (1915), Instytut Kultury i Oświaty im. S. Staszica (1919), Centralne Biuro Kursów dla Dorosłych (1930). W zakresie propagowania czytelnictwa działał Wydział Czytelń Bezpłatnych Warszawskiego Towarzystwa Dobroczynności (1891) i Towarzystwo Czytelni m.st. Warszawy (1906).

Towarzystwo Czytelni Ludowych w Poznaniu (TCL, 1880), (Macierz Szkolna Ziemi Cieszyńskiej (zał. w 1885 r. jako Macierz Szkolna dla Księstwa Cieszyńskiego), Uniwersytet Ludowy im. A. Mickiewicza we Lwowie (1898) i Krakowie (1899), PMS na Litwie w Wilnie (1919), a także Polskie Towarzystwo Krajoznawcze (1906), Związek Młodzieży Wiejskiej (1928), czy utworzona w 1920 r. Sekcja Oświatowa Centralnego Związku Kółek Rolniczych to kolejne organizacje, które rozwijały pracę oświatowo-kulturalną. Wymienić trzeba też Związek Teatrów i Chórów Włościańskich we Lwowie (1907)

\footnotetext{
wych władz szkolnych, Dz. U. 1933, nr 50, poz. 389.

4 Rozporządzenie Ministra Wyznań Religijnych i Oświecenia Publicznego z dnia 25 sierpnia 1933 r. o organizacji wewnętrznej obwodowych władz szkolnych, Dz. Urz. MWRiOP 1933, nr 11, poz. 163: „§ 8. W zakresie oświaty pozaszkolnej w swoim obwodzie jest inspektor szkolny odpowiedzialny: a) za badanie i znajomość potrzeb oświaty pozaszkolnej, czuwanie nad ich zaspokajaniem i organizowaniem pomocy fachowej, b) za inicjowanie i koordynowanie akcji społecznej w zakresie oświaty pozaszkolnej i kierowanie jej na właściwe tory, c) za utrzymywanie stałego kontaktu z organami samorządu terytorialnego i gospodarczego, jako też z odpowiednimi instytucjami społecznymi. $\S 11$. [...] Instruktor oświaty pozaszkolnej ponosi odpowiedzialność za dokładną znajomość stanu i potrzeb oświaty pozaszkolnej na terenie obwodu szkolnego oraz za umiejętne wykonanie powierzonych mu prac przy użyciu właściwych metod i środków".
}

5 Oświata pozaszkolna..., s. 352

6 Tamże, s. 353. 
przekształcony w 1919 r. w Związek Teatrów Ludowych w Warszawie, który organizował m.in. biblioteki stałe i wędrowne (ruchome) ${ }^{7}$.

Oświata pozaszkolna znajdująca się przed I wojną światową w rękach społeczeństwa otrzymała pewne wsparcie Wydziału Oświaty Pozaszkolnej MWRiOP, który wspomagał placówki społeczne dotacjami, dążąc do scalania i ujednolicenia akcji bibliotecznych różnych organizacji oświatowych, niezależnych w swoich działaniach ${ }^{8}$.

Ważną rolę w systemie edukacji pozaszkolnej pełniły biblioteki oświatowe. Informacje o ich stanie w II Rzeczypospolitej przyniósł pierwszy spis przeprowadzony w latach 1929-1930 (w zasadzie pomijał dane o bibliotekach szkolnych, naukowych i wojskowych). Z opublikowanego w 1932 r. wykazu bibliotek (używano też nazwy czytelnia) wynika, że w 1930 r. ogółem było w Polsce 8526 bibliotek oświatowych, z czego 60\% to placówki działające na wsi, przede wszystkim w województwach południowych i centralnych ${ }^{9}$. Niestety zasobność bibliotek była bardzo skromna, blisko 40\% placówek liczyło do 100 książek, a 51\% do 500. Na pięciu mieszkańców w Polsce przypadał zaledwie 1 tom $^{10}$. Poza tym w spisie odnotowano 3802 punkty biblioteczne, w większości wiejskie, nie wliczone do ogólnej liczby bibliotek oświatowych, obsługiwane przez biblioteki ruchome ${ }^{11}$.

Z wymienionych wyżej towarzystw najwięcej bibliotek prowadziło w 1930 r. TCL - 765 (339 209 tomów), Towarzystwo Szkoły Ludowej 471 (401 378) i PMS - 251 (287 571) 2 .

Najbardziej szczegółowe informacje do spisu bibliotek napłynęły z województwa łódzkiego ${ }^{13}$, do którego do roku 1938 należał powiat kaliski i turecki. Ogółem w tym województwie zarejestrowano 469 bibliotek, w tym 265 w miastach i 204 na wsi, zaś ich księgozbiór liczył ogółem 516737 tomów (455 261 w miastach, 61476 na wsi) $)^{14}$.

Z 32 bibliotek działających w powiecie kaliskim ze zbiorami liczącymi 39994 tomy, 13 było w Kaliszu: publiczna im. A. Mickiewicza (zał. w 1900 r.),

Tamże.

8 J. Muszkowski, Biblioteki oświatowe w Polsce, [w:] Książka w pracy oświatowej, kom. red. W. Dąbrowska, Z. Kobyliński, J. Muszkowski, Warszawa 1935, s. 32-33.

9 Biblioteki oświatowe. Spis na dzień 1 stycznia 1930 r. oraz tablice statystyczne, Warszawa-Lwów 1932, s. XIX.

10 Z. Gaca-Dąbrowska, Bibliotekarstwo II Rzeczypospolitej, Warszawa 2007, s. 40-41.

11 J. Muszkowski, Biblioteki oświatowe..., s. 31.

12 Z. Gaca-Dąbrowska, Bibliotekarstwo..., s. 41; materiały na temat zakładania i organizowania czytelni oraz bibliotek PMS opracował Józef Stemler (Instrukcje w sprawie prowadzenia oświaty pozaszkolnej przez koła i czytelnie Polskiej Macierzy Szkolnej, wyd. 3, rozszerz., Warszawa 1925).

13 Wskazują na to m.in. dwie tabele w pracy Biblioteki oświatowe. Spis... dotyczące tylko danych z woj. łódzkiego (tab. 16 i 17, s. XXX).

14 Biblioteki oświatowe. Spis..., s. XIX (tab. 1). 
miejska im. A. Asnyka (1927), dwie wypożyczalnie książek: Muszyńskiego (1924) oraz B. Praszkierówny (1928), biblioteki stowarzyszeń: Stowarzyszenia Robotników Chrześcijańskich „Ognisko” (1907), Biblioteka i Czytelnia im. J. Piłsudskiego Towarzystwa Uniwersytetu Robotniczego (1923), Stowarzyszenia Młodzieży Polskiej (SMP) Żeńskiej „Szarotka” (brak informacji o dacie założenia), Towarzystwa Kursów Wieczornych dla Robotników, im. Marszałka J. Piłsudskiego Związku Strzeleckiego (1923) oraz więzienna (ok. 1870), a także związkowe: Związku Zawodowego Kolejarzy (1919), Świetlicy Niższych Funkcjonariuszy P.P. (1926) i jedna żydowska im. J.I. Pereca Żydowskiego Klubu Gimnastyczno-Sportowego (1913) ${ }^{15}$. Warto dodać, że z Biblioteki Towarzystwa „Proswita” we Lwowie do biblioteki Stanicy Ukraińskiej w Kaliszu (1923) trafiło 50 tomów oraz 100 pozycji do Centralnego Komitetu Ukraińskiego w Szczypiornie. Pozostałe biblioteki funkcjonowały w następujących miejscowościach - cztery w Błaszkach: organizacji syjonistycznej (1916), SMP (1928), Towarzystwa Gimnastycznego „Sokół” (1929), organizacji „Szlomej Emunej Israel” (1929); dwie w Liskowie: parafialna (1910) i SMP Żeńskiej (1924); jedna w Koźminku (Czytelnia Ludowa im. H. Sienkiewicza, zał. 1917); pozostałe we wsiach Chlewo (SMP Męskiej i Żeńskiej, 1929); Dobrzec, dziś dzielnica Kalisza (SMP Żeńskiej, 1913); Godziesze Wielkie (parafialna, 1917); Korzeniew (Koła Młodzieży Wiejskiej KMW, 1929); Koźlątków (wiejska w szkole powszechnej, 1915); Nakwasin (KMW, 1929); Opatówek (Związku Strzeleckiego, 1928); Rajsko (parafialna, 1914); Stojanów (KMW, 1929); Szczypiorno, także obecnie dzielnica Kalisza (Drużyny Harcerskiej im. B. Głowackiego, 1926); Tłokinia Wielka (Czytelnia Ludowa „Świt” im. H. Sienkiewicza, 1914) i Zbiersk (czytelnia przy Cukrowni „Zbiersk”, 1910) ${ }^{16}$.

W powiecie tureckim działały 22 biblioteki, które dysponowały 9696 tomami, z których siedem działało w Turku: Związku Zawodowego Robotników Rolnych (zał. w 1920 r.), Policyjnego Klubu Sportowego „Siła” (1921), SMP Męskiej i Żeńskiej (1927), Związku Nauczycielstwa Polskiego (ZNP, 1924), Drużyny Harcerskiej im. T. Kościuszki (1924), Drużyny Harcerskiej im. ks. J. Poniatowskiego (1915) oraz organizacji syjonistycznej $(1915)^{17}$; cztery w Uniejowie: ZNP (1921), SMP (1928), Kółka Literacko-Dramatycznego i Żydowska im. J.L. Pereca (1926); dwie w Dobrej: Towarzystwa im. A. Mickiewicza (brak inf. o dacie założenia) i SMP (1926); pozostałe w Boleszczynie (czytelnia parafialna), Chwalborzycach (SMP Męskiej i Żeńskiej, 1925), Ewinowie (KMW, 1927), Kossowie (KMW, 1922),

\footnotetext{
15 Tamże.

16 Tamże, s. 23-24 (powiat kaliski).

17 Tamże, s. 33-34 (powiat turecki).
} 
Pęczniewie (PSL „Wyzwolenie”, 1928), Proboszczowicach (gminna, 1928), Skęczniewie (Biblioteka Powszechna im. H. Sienkiewicza, 1917), Świnicach (Domu Ludowego, 1929) i Wilamowie (Stowarzyszenia Młodzieży Katolickiej, 1926) ${ }^{18}$.

Rozwój bibliotekarstwa oświatowego w 20-leciu międzywojennym zawdzięczamy również samorządowi terytorialnemu. Dzięki prowadzonej przezeń akcji bibliotecznej liczba bibliotek samorządowych z 233 w roku 1929 wzrosła do 1033 w 1938 r. Zwiększyła się także liczba powiatowych samorządowych central bibliotecznych z 23 (1929) do 139 (1938 r.) ${ }^{19}$.

\section{Charakterystyka omawianego dokumentu}

W zbiorach nielicznych bibliotek zachował się interesujący dokument, stanowiący instrukcję organizowania i prowadzenia oświaty pozaszkolnej na obszarze powiatów kaliskiego i tureckiego, wydany przez kaliski Inspektorat Szkolny w 1936 r. pod tytułem Wytyczne organizowania i prowadzenia oświaty pozaszkolnej ${ }^{20}$. Podobne instrukcje wydały także inspektoraty w Płocku (1935) i Włocławku (1936), przy czym włocławska instrukcja ${ }^{21}$, nieco obszerniejsza od kaliskiej, sprawom bibliotek i czytelnictwa poświęciła więcej miejsca, w tym także konkursom dobrego czytania książki, przytaczała też więcej przykładów form pracy kulturalno-oświatowej. Płockie wytyczne z kolei omawiały: szkoły wieczorowe dla dorosłych i młodzieży oraz kursy dokształcające (nauki obywatelskiej, przysposobienia rolniczego, rolniczy, dla gospodyń wiejskich, pszczelniczy). Ponadto dołączono obszerną Instrukcję dla zespołów konkursu dobrego czytania książki².

Wspomniane edycje świadczą, iż w wymienionych powiatach władze oświatowe poważnie podeszły do problemu nauczania pozaszkolnego, usiłując poprzez wydanie instrukcji ułatwić organizację tego obszaru działań edukacyjnych. Trzeba jednak stwierdzić, iż aktywność w tej mierze zaledwie trzech obwodów oświatowych na terenie dwóch kuratoriów okręgów szkolnych świadczyć może o marginalnym traktowaniu tego zagadnienia.

Analizowany druk wyszedł spod pras działającej w Kaliszu od 1921 r. Drukarni Ziemi Kaliskiej, której właścicielami było pięciu udziałowców, w tym

18 Tamże.

19 J. Janiczek, Bibliotekarstwo oświatowe w Polsce po dwudziestu latach niepodległości, „Bibliotekarz" 1939, nr 1-2, s. 3.

20 Obecność egzemplarzy druku odnotować możemy w zasobach Biblioteki Narodowej w Warszawie, a także księgozbiorze Kaliskiego Towarzystwa Przyjaciół Nauk. Druk dostępny jest również w Pedagogicznej Bibliotece Cyfrowej w Krakowie http://pbc.up.krakow.pl/dlibra/docmetadata? $\mathrm{id}=5406$

21 Wytyczne organizowania i prowadzenia oświaty pozaszkolnej, Włocławek 1936.

22 Wytyczne organizowania i prowadzenia oświaty pozaszkolnej, Płock 1935. 
Bank Ziemi Kaliskiej. W roku 1923 pracę na stanowisku kierownika drukarni rozpoczął Antoni Krawczyk, który w lipcu 1937 r. kupił drukarnię i uruchomił ją pod nazwą Chrześcijańska Drukarnia Ziemi Kaliskiej. W latach 19211935 Drukarnia Ziemi Kaliskiej produkowała przede wszystkim wydawnictwa o charakterze użytkowym i okolicznościowym. Poza tym spod jej pras wyszło wiele tytułów dotyczących Kalisza, m.in. prace Józefa Radwana, Kazimierza Stefańskiego, Jerzego Kowalewskiego-Dołęgi, publikacje o tematyce religijnej, druki jubileuszowe, statuty i sprawozdania, a także miejscowe pisma np. „ABC Kaliskie”, „Głos Kaliski” czy periodyki szkolne np. „Sztubak”, „Czyn i Słowo”. Firma tłoczyła też wydawnictwa „Ligi Pracy” w Warszawie ${ }^{23}$.

\section{Zawartość dokumentu}

Twórcy Wytycznych... podkreślali, że choć „ilość form pracy oświatowej nie jest ściśle określona" to by mieć pewną orientację wymienili najbardziej popularne. Znalazły się tu:

1. Kursy systematycznego kształcenia,

2. Kursy dokształcające,

3. Świetlice,

4. Uniwersytety Niedzielne,

5. Uniwersytety Ludowe sobotnio-niedzielne,

6. Biblioteki i czytelnie,

7. Teatr ludowy,

8. Orkiestry i chóry,

9. Przysposobienie rolnicze,

10. Badanie środowiska ${ }^{24}$.

Z proponowanych powyżej form pracy oświatowej pracownik w terenie wybierał jedną, w zależności od potrzeb środowiska, a w Wytycznych... omówiono pokrótce wszystkie.

Zadaniem kursów systematycznego kształcenia było przygotowanie młodzieży i dorosłych do egzaminów w zakresie siedmioklasowej publicznej szkoły powszechnej ${ }^{25}$. Celem kursów dokształcających z kolei było: 1) uzupełnianie zakresu wiadomości ogólnych potrzebnych każdemu obywatelowi niezależnie od pełnionej w życiu roli i 2) zwalczanie i niedopuszczanie do powtórnego analfabetyzmu. Poza zajęciami dokształcającymi ogólnokształcącymi proponowano organizowanie kursów poświęconych szczegółowym

23 Szerzej o drukarni Ziemi Kaliskiej patrz: E. Andrysiak, Drukarstwo kaliskie okresu międzywojennego w świetle bibliografii druków kaliskich, „Zeszyty Kaliskiego Towarzystwa Przyjaciół Nauk" 2006, nr 9, s. 121-123.

$24 \quad$ Wytyczne organizowania..., s. 4.

25 Tamże, s. 4-5. 
zagadnieniom - np. cykl wykładów nauki obywatelskiej, kurs historii Polski, kurs języka polskiego ${ }^{26}$.

W przypadku świetlic autorzy, ze względu na obszerny materiał, podali tylko „garść uwag” związanych z pracą świetlicową, na podstawie których kierownik świetlicy rozwijając też własne doświadczenia korzystał z materiału zamieszczonego w Wytycznych...

Przedstawione uwagi dotyczyły: celu działania świetlic, ich rodzajów (organizacyjne i pozaorganizacyjne tzw. oświatowe), doboru świetliczan, programu pracy, zespołów działających w świetlicy, lokalu przeznaczonego na pracę świetlicową. Jednym z typów realizowanych zajęć były wieczory świetlicowe dowolne, przeznaczone m.in. na czytanie pism, słuchanie radia, ciche czytanie książek ${ }^{27}$.

„Uniwersytety Niedzielne”, jak sama nazwa wskazuje, prowadziły wykłady w niedziele, $w$ wielu jednak wypadkach pracownicy oświatowi organizowali je w inne dni. Na jedno spotkanie składały się dwie godziny wykładu i godzina przeglądu prasy, tzw. gazety głośnej. Program obejmował aktualne zagadnienia, wiadomości z zakresu nauki o państwie, jego gospodarce i ustroju, kulturze (40 godzin wykładów i 20 godzin gazety głośnej). Podkreślano przy tym znaczenie prasy:

Przegląd prasy jest rzeczą bardzo ważną. Trzeba tu mieć do dyspozycji kilka dzienników, ażeby w toku referowania różnych zagadnień, wysuwanych przez prasę, konfrontować wiadomości i artykuły, naświetlające pewne zjawiska społeczne i polityczne. Czytanie jednej gazety nie da pożądanego rezultatu ${ }^{28}$.

Pracownicy oświatowi otrzymali także w Wytycznych... spis 40 tematów, które miały posłużyć do opracowania programu uniwersytetu niedzielnego. Dwa z nich można uznać za bliskie bibliotekarzom:

- Czytelnictwo, jako forma samokształceniowa, literatura zawodowa, piękna, biblioteki u nas i zagranicą. Przez czytelnictwo do podniesienia kultury,

- Obecny stan naszego piśmiennictwa, nasi wielcy pisarze i poeci doby dzisiejszej, laureaci Nagrody Nobla, artyści, malarze ${ }^{29}$.

Natomiast celem „Uniwersytetu Ludowego” przeznaczonego dla młodych rolników było przygotowanie liderów pracy społeczno-kulturalnej na $\mathrm{wsi}^{30}$. W Wytycznych... zwrócono uwagę na rolę amatorskiego teatru ludowego, poprzez który:

wyzwala się wartości wyższe, zdolności artystyczne. [...] zbliża się wielką kulturę do wsi, budzi się w masach poczucie, że i one biorą udział w tworzeniu kultury, koncentruje wysiłki

\footnotetext{
26 Tamże, s. 5-6.

27 Tamże, s. 6-11.

28 Tamże, s. 11.

29 Tamże, s. 14.

30 Tamże, s. 15-16.
} 
i zainteresowania wokół rzeczy oderwanych od codziennych czarnych trosk życia, dyscyplinuje i wychowuje społecznie ${ }^{31}$.

Podobnie jak teatr ludowy mile widzianą formą pracy kulturalnej było tworzenie chórów i orkiestr ${ }^{32}$. W dziale rolniczym dużym zainteresowaniem cieszyły się zespoły przysposobienia rolniczego ${ }^{33}$. Jako przykład nowej formy pracy oświatowej, wcześniej niestosowanej na terenie obwodu kaliskiego, wymieniano badanie środowiska ${ }^{34}$.

Pracownicy kulturalno-oświatowi otrzymali też w Wytycznych... pomoce w postaci regulaminów i planów pracy komisji oświatowo-społecznych rejonowych, gminnych i miejskich, służących organizacji pracy oświatowej w terenie, w których można znaleźć zapisy dotyczące bibliotek i czytelnictwa czasopism jako form pracy czy zapewnienia środków w budżecie z przeznaczeniem na bibliotekę ${ }^{35}$.

Wytyczne... zwracały także uwagę na stałe dokształcanie się pracowników oświaty, na czytanie przez nich książek i czasopism oraz uczestniczenie w kursach i konferencjach oświatowych: „Pomimo trudnych warunków materialnych zbiorowa prenumerata czasopism i dzienników, oraz zakup książek jest zawsze możliwa przy dobrej woli i zrozumieniu naszych zadań, jako pracowników oświatowych" "36. W spisie 24 wybranych wydawnictw oświatowych, „które winny znaleźć się w rękach każdego oświatowca" były m.in.: Książka w pracy oświatowej pod redakcją Wandy Dąbrowskiej, Zygmunta Kobylińskiego i Jana Muszkowskiego (Warszawa 1935), Wybrane zagadnienia oświatowe. Sześć referatów, wygłoszonych na wszechświatowej konferencji oświaty dorostych w Cambridge (Warszawa 1931), Heleny Radlińskiej Książka wśród ludzi (Warszawa 1929), Władysława Spasowskiego Zasady samokształcenia (Warszawa 1923), Stefana Rudniańskiego Technologia pracy umysłowej (higiena, organizacja, metodyka) wydana w Warszawie w 1933 r., Janiny Skarżyńskiej Jak czytać książki i gazety. Instrukcja dla samouków i kółek kształcenia (Warszawa 1934). Poza tym odnotowano tytuły czasopism niezbędnych w pracy oświatowców: „Oświata Pozaszkolna”, „Praca Oświatowa”, „Przewodnik Pracy Społecznej” - dodatek do „Głosu Nauczycielskiego”, ,Wiedza i Życie”, ,Teatr Ludowy"37.

\footnotetext{
1 Tamże, s. 19.

Tamże, s. 20.

Tamże, s. 20-21.

Tamże, s. 21-29.

Tamże, s. 31-41.

Tamże, s. 41.

Tamże, s. 41-43.
} 
Biblioteka i jej rola w organizowaniu i prowadzeniu oświaty pozaszkolnej w świetle Wytycznych... Inspektoratu Szkolnego w Kaliszu

\section{Zasady ogólne}

Biblioteki i czytelnie jako forma pracy oświatowej wymienione zostały w kaliskich Wytycznych... na szóstym miejscu. Ich omówieniu poświęcono jednak mniej uwagi niż świetlicom czy „Uniwersytetom Niedzielnym”. Według dokumentu w kaliskim obwodzie szkolnym ${ }^{38}$ działały:

1. Powiatowe Centrale Bibliotek Ruchomych w Kaliszu i Turku (razem 55 szafek),

2. biblioteki gminne w początkach działalności w czterech miejscowościach (Grzybki, Zbiersk, Lisków, Tokary),

3. biblioteki organizacyjne.

Zakładano zatem, że zaspokajanie potrzeb czytelniczych w terenie można realizować poprzez wypożyczanie kompletów książek ${ }^{39}$ z Centrali Powiatowej Bibliotek Ruchomych, tworzenie kolejnych bibliotek gminnych oraz „,uaktywnienie bibliotek organizacyjnych" ${ }^{40}$. Ze względu na małą liczbę kompletów ruchomych powiatowe centrale miały ograniczone możliwości działania. Biblioteki organizacyjne z kolei bez stałego finansowania nie miały także możliwości zakupu książek, co powodowało, że stawały się księgozbiorami martwymi. Stąd nastawienie na tworzenie bibliotek gminnych, działających w oparciu o fundusze samorządu gminnego, umożliwiające choćby minimalne zakupy książek każdego roku ${ }^{41}$.

W Wytycznych... zwracano uwagę na fakt, że samo wypożyczenie książki jest proste, ale ważne są formy pracy z książką w każdej bibliotece, także tej najmniejszej. Podkreślano, że trzeba znać potrzeby czytelników, prowadzić z nimi rozmowy i dyskusje na temat przeczytanych książek, organizować

38 Obwód kaliski obejmujący powiaty kaliski i turecki, z siedzibą inspektora szkolnego w Kaliszu, był w Okręgu Szkolnym Warszawskim - Rozporządzenie Ministra Wyznań Religijnych i Oświecenia Publicznego z dnia 14 lipca 1933 r. o podziale okręgów szkolnych na obwody szkolne (Dz. U. 1933, nr 61, poz. 459). W 1938 r. na podstawie Rozporządzenia Ministra Wyznań Religijnych i Oświecenia Publicznego z dnia 8 lutego w sprawie zmiany rozporządzenia z dnia 14 lipca $1933 \mathrm{r}$. o podziale okręgów szkolnych na obwody szkolne (Dz. Urz. MWRiOP 1938, nr 2, poz. 26) utworzono obwód szkolny kaliski i obwód szkolny turecki i włączono je do okręgu szkolnego poznańskiego.

39 Wielkość kompletu biblioteki ruchomej PMS wahała się od 50 do 150 książek. - J. Stemler, Instrukcje w sprawie..., s. 80. Z kolei według Zofii Rodziewiczowej komplet ruchomy biblioteki publicznej liczył od 50 do 75 tomów. - Z. Rodziewiczowa, Badanie terenu i organizacja sieci bibliotecznej w powiecie, [w:] Książa w pracy oświatowej..., s. 54-55.

40 Wytyczne organizowania..., s. 16.

41 Tamże. 
wieczory wspólnego czytania. A ostatnią z wymienionych form pracy - wieczory głośnego czytania - można realizować nawet przy kilku książkach, których brak na miejscu nie stanowił przeszkody, można je bowiem było wypożyczyć z najbliższej biblioteki (gminnej lub ruchomej) ${ }^{42}$.

\section{Powiatowe centrale bibliotek ruchomych i ich regulamin}

Powiatowe Centrale Bibliotek Ruchomych w Kaliszu i Turku posiadały swoje regulaminy, których znajomość była obowiązkowa dla pracowników oświaty. Regulaminy dołączane były do kompletów ruchomych. Pierwszy punkt regulaminu Powiatowej Centrali Bibliotek Ruchomych mówił, że stanowi ona własność Związku Samorządowego, kolejne określały zasady korzystania z kompletów bibliotecznych. Zasady wypożyczania ustalała Komisja Oświaty Pozaszkolnej, kierując książki do mieszkańców o różnym poziomie potrzeb oświatowych i kulturalnych, także w celu zasilenia bibliotek gminnych czy uniwersytetów ludowych. Funkcję kierowników bibliotek ruchomych i jednocześnie ich bibliotekarzy pełnili nauczyciele publicznych szkół powszechnych, którzy nie mogli zmieniać zawartości kompletu ani przekazywać go innej miejscowości. Inspektor oświaty pozaszkolnej we współpracy z nauczycielami opracowywał plan rozmieszczenia kompletów biblioteki ruchomej w terenie, które wypożyczane były z Centrali Bibliotek Ruchomych na okres od 1 października do 1 czerwca, czyli na rok oświatowy. Istniała też, w wyjątkowych wypadkach, możliwość wymiany biblioteki dwa razy w ciągu roku oświatowego. Czas od czerwca do października wykorzystywano na sprawdzanie biblioteczek, ich uporządkowanie oraz przygotowanie do ponownego wysłania w teren. Nieprzestrzeganie zasad regulaminu skutkowało pozbawieniem danej miejscowości prawa do korzystania z Centrali Bibliotek Ruchomych. Uwagi czytelników związane z doborem książek w danym komplecie oraz dotyczące czytelnictwa w danym środowisku zgłaszali do Centrali Bibliotek Ruchomych kierownicy punktów ${ }^{43}$.

Obowiązki kierownika punktu regulowała osobna instrukcja, której punkt drugi mówił, że wypożyczanie biblioteczek jest bezpłatne. Określała też termin wypożyczenia biblioteczki z centrali (od 1 października do 1 czerwca), obowiązki kierownika, do których należało m.in. sprawdzenie zawartości biblioteczki i kwitowanie odbioru, wyznaczenie dni i godzin wypożyczania, z zastrzeżeniem, że musi się to odbywać co najmniej dwa razy w tygodniu, $\mathrm{w}$ tym jeden dzień powinien przypadać na niedzielę. Bibliotekarzowi zalecano, by zapoznał się z treścią otrzymanych książek, przygotował pogadankę

\footnotetext{
42 Tamże, s. 16-17.

43 Tamże, s. 17-18.
} 
o czytelnictwie, zorganizował wieczór promocji książek oraz wieczory głośnego czytania. Kierownik prowadził podwójną kontrolę wypożyczeń: książki i czytelnika, a karty książki razem ze sprawozdaniem i biblioteką (kompletem książek) wracały do Centrali Bibliotek Ruchomych ${ }^{44}$. Dodatkowo w instrukcji dla kierownika punktu zamieszczona została uwaga: „Pisać ołówkiem zwykłym, dobrze zaostrzonym, wyraźnie ale drobno, jeden wiersz musi wystarczyć na jedno wypożyczenie" 45 .

Osobny był też regulamin Powiatowej Centrali Bibliotek Ruchomych dla czytelników, w którym określono godziny otwarcia biblioteki, wiek osób mogących z niej korzystać, liczbę wypożyczanych książek (jeden tom), termin wypożyczeń oraz kary za przetrzymywanie woluminów. W punkcie trzecim zaznaczono, że korzystanie z biblioteki jest bezpłatne. Punkt siódmy regulaminu z kolei mówił, że „Książki trzeba owijać w papier. W domu należy mieć książkę obłożoną. Odnosząc do biblioteki również owijać w papier aby książki nie niszczyć" ${ }^{4}$. Wypożyczając książkę czytelnik zobowiązany był do zgłaszania zauważonych uszkodzeń, za książkę zagubioną z kolei płacił karę w wysokości określonej przez kierownika. Prawa korzystania z biblioteki czytelnika pozbawiano w przypadku choroby zakaźnej oraz niestosowania się do regulaminu.

Doceniając znaczenie oświatowej akcji pozaszkolnej wydziały powiatowe (powiatów kaliskiego i tureckiego) w listopadzie 1936 r. skierowały do zarządów gminnych pismo z wytycznymi dotyczącymi działań społeczno-oświatowych na terenie gminy i gromady. Zalecano w nim by w budżetach gminnych na rok 1937-1938 w dziale oświata pozaszkolna uwzględniły środki na biblioteki, kursy dokształcające, świetlice i pomoc dla pracowników oświatowych ${ }^{47}$.

Pośród zadań gromady w zakresie prac oświatowych na uwagę według Wytycznych ... zasługiwały: świetlice, kursy wieczorowe, uniwersytety ludowe, czytelnie, biblioteki. Potrzebę tworzenia tych ostatnich uzasadniano tak:

Dążeniem każdej gromady powinno być posiadanie czytelni oraz biblioteki. Dzisiaj niewielu mieszkańców gromady może prenumerować pisma, a wielu chętnie przeczytałoby wiadomości i nowiny z kraju i z zagranicy oraz wiadomości gospodarskie; to też czytelnia gromadzka powinna posiadać co najmniej kilka pism.

Trudniej jest na wsi o bibliotekę, należałoby ją jednak zapoczątkować, a nim to nastąpi, wypożyczać komplety książek z biblioteki ruchomej ${ }^{48}$.

Dodano również, że: „We własnym lokalu gromada łatwiej będzie mogła zorganizować bibliotekę, czytelnię, przez co uprzystępni zdobywanie wiedzy

\footnotetext{
44 Tamże, s. 18.

45 Tamże.

46 Tamże, s. 19.

47 Tamże, s. 44.

48 Tamże, s. 46-47.
} 
i kultury wszystkim obywatelom gromady"49. Co ciekawe, Wytyczne ... podawały przykład wzorowego domu gromadzkiego, posiadającego: salę zebrań ze sceną, służącą także jako sala gimnastyczna, pomieszczenia na biuro sołtysa i organizacji społecznych, świetlicę z czytelnią i biblioteką, lokal dla działających w gromadzie spółdzielni, remizę strażacką i sportową w suterenie oraz łaźnię ${ }^{50}$.

\section{Zakończenie}

J. Muszkowski w 1935 i Józef Janiczek w 1939 r. omawiając problemy bibliotekarstwa oświatowego ${ }^{51}$ zauważali, że mimo wzrostu liczby bibliotek oświatowych, punktów bibliotecznych, księgozbiorów, czytelników i wypożyczeń oraz udziału samorządów w akcji bibliotecznej, dotychczasowe prace w tym zakresie powinny być nadal kontynuowane. Choć wkład bibliotekarstwa w kulturę oceniano pozytywnie to według Janiczka nie był duży. ${ }^{52}$ Wpływ na taki stan rzeczy miał m.in. brak ustawy bibliotecznej, choć prace nad nią wznawiane były kilka razy (po raz pierwszy w 1921 r., później w latach 1927, 1928, 1930, 1934, 1936).

Wytyczne organizowania i prowadzenia oświaty pozaszkolnej stanowiły pomoc w tym zakresie na terenie obwodu obejmującego powiat kaliski i turecki, choć z pewnością nie wyczerpywały tematu. Krótkie z konieczności omówienia najbardziej popularnych form pracy oświatowej, przykładowe regulaminy czy plany pracy ułatwiały prowadzenie działalności kulturalno-oświatowej, w tym tworzenie bibliotek ruchomych.Na stan czytelnictwa wpływ miały dostępność i czas funkcjonowania bibliotek. Zarówno w Kaliszu i powiecie kaliskim, jak i Turku i powiecie tureckim część bibliotek wypożyczała zbiory za opłatą, a pewna grupa księgozbiorów przeznaczona była dla ograniczonego kręgu użytkowników. Także czas udostępniania limitowany do kilku godzin bądź dwóch dni w tygodniu z pewnością nie sprzyjał rozwojowi czytelnictwa.

Autorzy kaliskich Wytycznych... pisali:

Książka dla oświatowca jest pierwszorzędnym narzędziem pracy. Starania w kierunku tworzenia bibliotek, które w sposób właściwy i fachowy rozpowszechniałyby książki wśród najszerszych mas obywateli, jest pracą najbardziej pożądaną i pilną ${ }^{53}$.

Słowa te do dziś nie straciły na znaczeniu.

\footnotetext{
49 Tamże, s. 47.

50 Tamże.

51 J. Muszkowski, Biblioteki oświatowe..., s. 30-35, J. Janiczek, Bibliotekarstwo oświatowe..., s. 6 .

52 J. Janiczek, Bibliotekarstwo oświatowe..., s. 6.

53 Wytyczne organizowania..., s. 16.
} 


\section{Bibliografia}

Źródła drukowane

Biblioteki oświatowe. Spis na dzień 1 stycznia 1930 r. oraz tablice statystyczne, Warszawa-Lwów 1932.

Podręczna encyklopedia pedagogiczna. Wraz z dodatkiem i dwoma indeksami. T. 2: N-Ż, oprac. F. Kierski, Lwów-Warszawa 1925.

Rozporządzenie Ministra Wyznań Religijnych i Oświecenia Publicznego z dnia 14 lipca 1933 r. o podziale okręgów szkolnych na obwody szkolne, Dz. U. 1933, nr 61, poz. 459.

Rozporządzenie Ministra Wyznań Religijnych i Oświecenia Publicznego z dnia 25 sierpnia 1933 r. o organizacji wewnętrznej obwodowych władz szkolnych, Dz. Urz. MWRiOP 1933, nr 11, poz. 163.

Rozporządzenia Ministra Wyznań Religijnych i Oświecenia Publicznego z dnia 8 lutego w sprawie zmiany rozporządzenia z dnia 14 lipca 1933 r. o podziale okręgów szkolnych na obwody szkolne, Dz. Urz. MWRiOP 1938, nr 2, poz. 26.

Rozporządzenie Prezydenta Rzeczypospolitej z dnia 4 lipca 1933 r. o organizacji obwodowych władz szkolnych, Dz. U. 1933, nr 50, poz. 389.

Władze szkolne w latach 1917/18-1937/38. Zbiór ustaw, dekretów, rozporzadzeń, okólników i zarzadzeń, dotyczacych ustroju i organizacji władz szkolnych Rzeczypospolitej Polskiej, oprac. T. Serafin, Warszawa 1938.

Wytyczne organizowania i prowadzenia oświaty pozaszkolnej, Kalisz 1936.

Wytyczne organizowania i prowadzenia oświaty pozaszkolnej, Włocławek 1936.

Wytyczne organizowania i prowadzenia oświaty pozaszkolnej, Płock 1935.

Opracowania

Andrysiak E., Drukarstwo kaliskie okresu międzywojennego w świetle bibliografii druków kaliskich, „Zeszyty Kaliskiego Towarzystwa Przyjaciół Nauk” 2006, nr 9, s. 119-132.

Gaca-Dąbrowska Z., Bibliotekarstwo II Rzeczypospolitej. Zarys problemów organizacyjnych i badawczych, Warszawa 2007, Nauka, Dydaktyka, Praktyka, 93.

Janiczek J., Bibliotekarstwo oświatowe w Polsce po dwudziestu latach niepodległości, „Bibliotekarz” 1939, nr 1-2, s. 1-7.

Malinowska E., Organizacja pracy w wiejskiej bibliotece stałej i ruchomej, [w:] Książka w pracy oświatowej, [kom. red. W. Dąbrowska, Z. Kobyliński, J. Muszkowski], Warszawa 1935, s. 60-67.

Muszkowski J., Biblioteki oświatowe w Polsce, [w:] Książka w pracy oświatowej, [kom. red. W. Dąbrowska, Z. Kobyliński, J. Muszkowski], Warszawa 1935, s. 26-47.

Nowak J., Oświata dorosłych - cele, zadania, funkcje, uczestnicy [hasło], [w:] Encyklopedia oświaty i kultury dorostych, pod red. K. Wojciechowskiego, przy współpracy C. Maziarza, J. Nowak, Wrocław 1986, s. 207-208. 
Rodziewiczowa Z., Badanie terenu i organizacja sieci bibliotecznej w powiecie, [w:] Książka w pracy oświatowej, [kom. red. W. Dąbrowska, Z. Kobyliński, J. Muszkowski], Warszawa 1935, s. 48-59.

Stemler J., Instrukcje w sprawie prowadzenia oświaty pozaszkolnej przez koła i czytelnie Polskiej Macierzy Szkolnej. Wyd. 3 rozszerzone, Warszawa 1925. 
